\title{
Deicing Salts Reduce Cold Hardiness and Increase Flower Bud Mortality of Highbush Blueberry
}

\author{
Steven F. Berkheimer and Eric Hanson 1 \\ Department of Horticulture, Plant and Soil Science Building, Michigan State University, East Lansing, \\ MI 48824
}

\begin{abstract}
AdDitional INDEX wORDs. Vaccinium corymbosum, sodium chloride, potassium chloride, sodium acetate, magnesium chloride, calcium chloride, winter hardiness

ABSTRACT. Injury has been observed since the early to mid-1990s to highbush blueberries (Vaccinium corymbosum L.) growing along roads in southern Michigan. Symptoms include shoot dieback, flower bud mortality, and reduced yields. To determine if this injury was the result of deicing salts applied to roads, salt (sodium chloride, $\mathrm{NaCl}$ ) spray was applied to potted blueberry plants, and to the plant root zones. Bushes sprayed six times during the winter with NaCl solutions $(0,0.034,0.068,0.137,0.274,0.548 \mathrm{M})$ developed the same injury symptoms observed in roadside fields, and injury severity was proportional to the spray concentration. The root media of other potted plants was saturated with $\mathrm{NaCl}$ solutions $(0,0.017,0.051,0.154$, and $0.462 \mathrm{M})$ in Mar. 2002. Pots were then rinsed with fresh well water when growth began in April to determine if soil salt caused similar damage. The highest soil salt levels killed most above ground growth, and damage diminished with decreasing salt levels. Twigs were also excised from branches sprayed twice with $\mathrm{NaCl}$ solutions or water and frozen incrementally to measure the temperature resulting in $50 \%$ flower bud mortality $\left(\mathrm{LT}_{50}\right)$. Salt exposure reduced the $\mathrm{LT}_{50}$ of flower buds, by as much as $11.5^{\circ} \mathrm{C}$, relative to the control, even within 2 days of treatment. Additional studies with chloride salts $\left(\mathrm{NaCl}, \mathrm{KCl}, \mathrm{CaCl}_{2}, \mathrm{MgCl}_{2}\right)$ and sodium salts $(\mathrm{NaCl}$, Na-acetate, $\mathrm{Na}_{2} \mathrm{SO}_{4}$ ) indicated that most reduced the cold tolerance of blueberry flower buds to some degree.
\end{abstract}

Many roads in northern areas are treated with deicing salts to melt ice and snow and help maintain safe road surfaces. Sodium chloride is the most widely used deicing material in the north central and eastern United States [Michigan Dept. of Transportation (MDOT), 1993] because it is inexpensive and effective. However, $\mathrm{NaCl}$ can damage roadside trees and shrubs (Bowers and Hesterberg, 1976; Bryson and Barker, 2002; MDOT, 1993; Lumis et al., 1976). Symptoms of injury include dieback of branches and buds and browning of conifer needles in late winter/early spring, witch's broom growth from branch ends, reduced flowering and foliar growth, and plant death in extreme cases (Sucoff, 1975).

Roadside plants may be injured by excessive soil salt levels or by salt spray that is generated by traffic and deposited on aerial plant parts by wind. The relative importance of these two types of exposure has been debated (Thompson and Rutter, 1986). Soil salt injury tends to be confined to plants within $5 \mathrm{~m}$ of roads (Bryson and Barker, 2002), and can result in leaf chlorosis and reduced photosynthetic rates that persist through the following season (Paludan-Muller et al., 2002), and may result in a general plant decline and death (MDOT, 1993; Sucoff, 1975). Salt spray injury can occur $100 \mathrm{~m}$ or more from roads and generally includes dieback of shoots and branches (Northover, 1987), reduced flowering (Northover, 1987), and browning of conifer needles in late winter/early spring (MDOT, 1993; Sucoff, 1975; Zobel and Nighswander, 1990). Plants with low or moderate levels of salt spray injury tend to recover after a season (Thompson and Rutter, 1986).

The effects of high soil salt levels on plant growth generally includes inhibited water uptake and resulting drought stress, toxicity associated with excessive accumulation primarily $\mathrm{Na}$ (sodium) and $\mathrm{Cl}$ (chloride) in tissues, and nutrient imbalances resulting from impaired uptake or translocation (Marschner, 1995). How

Received for publication 24 May 2005. Accepted for publication 12 July 2005. 1To whom reprint requests should be addressed. E-mail: hansone@msu.edu
$\mathrm{NaCl}$ spray injures roadside woody plants is not clear, although one specific effect of $\mathrm{NaCl}$ spray exposure might be reduced cold hardiness of woody tissues (Sucoff, 1975; Sucoff and Hong, 1976; Sucoff et al., 1976). This may explain why exposure to $\mathrm{NaCl}$ and extreme cold often cause similar symptoms, and why salt injury is most severe when accompanied by colder winter conditions (Berkheimer, 2004; Sucoff et al., 1976).

Sucoff (1975) suggested that salt residues on tissue surfaces may cause injury by desiccating cells, whereas others have speculated that injury from salt spray may be a toxic response to excessive $\mathrm{Na}$ or $\mathrm{Cl}$, perhaps compromising hardiness by disrupting cell membranes (Zobel and Nighswander, 1990). Surface applied Na and $\mathrm{Cl}$ enters dormant woody twig and bud tissues (Barrick and Davidson, 1980) and $\mathrm{Na}$ and $\mathrm{Cl}$ levels typically accumulate in the twigs of roadside plants during the winter (Lumis et al., 1976). Sucoff (1975) proposed salt enters dormant shoots via leaf traces. If the reduced hardiness or tissue injury caused by $\mathrm{NaCl}$ sprays is a toxic effect of $\mathrm{Na}$ or $\mathrm{Cl}$, alternative deicers that do not contain $\mathrm{Na}$ (e.g., $\mathrm{MgCl}_{2}, \mathrm{KCl}, \mathrm{CaCl}_{2}$ ) or $\mathrm{Cl}$ (Na-acetate) should have less effect on hardiness and may be less injurious to woody plants. Several alternative deicing materials are used to a limited extent, but their phytotoxicity relative to $\mathrm{NaCl}$ is not known.

Highbush blueberry plantings along roads in western Michigan exhibited twig dieback and flower bud mortality that was closely associated with exposure to deicing salt (Berkheimer, 2004). Bushes closest to heavily traveled roads often suffered complete flower bud loss, and injury was lower farther from the roads and in fields located upwind (west) of roads. Salt deposition on twigs was also greatest closest to the road, although levels fluctuated during the winter months. Similar injury in lowbush blueberry (Vaccinium angustifolium Ait.) fields next to Nova Scotia highways was attributed to road salt spray (Eaton et al., 1999), and salt water spray also caused injury in fields near ocean bays (Eaton et al., 2004). Salt spray injury in an Ontario peach (Prunus persica L.) orchard extended $100 \mathrm{~m}$ into the orchard, and included twig dieback and yield reductions (Northover, 1987). 
Salt spray may severely affect fruiting of blueberries because flower buds are borne on the exposed terminals of the previous years' growth. Cold injury often limits yields in Michigan blueberries, so even a small reduction in hardiness associated with salt exposure could result in substantial yield losses during some years.

The objectives of this research were to determine if the injury observed on roadside blueberries could be induced by spraying young plants or treating soil with $\mathrm{NaCl}$. We were also interested in determining how $\mathrm{NaCl}$ and other salts affect the cold tolerance of blueberry.

\section{Materials and Methods}

Salt SPRay Simulation. Thirty 'Bluecrop' blueberry plants in 7.6-L containers ( $\approx 5$ years old and $1 \mathrm{~m}$ tall) were heeled into the ground in Dec. 2001 in a lathouse in East Lansing, Mich. Plants were sprayed to run-off on $7 \mathrm{Jan}$. 2002 with $\mathrm{NaCl}$ solutions of $0,0.034,0.068,0.137,0.274$, or $0.548 \mathrm{M} \mathrm{NaCl}$ using a backpack sprayer. Aluminum foil was placed around the base of pots to prevent solutions from entering the soil. A screen was used to shield adjacent plants. Sprays were repeated five times at 2-week intervals thereafter.

Salt deposition on twig surfaces was measured before each application by collecting one twig from each plant and placing them in $50-\mathrm{mL}$ centrifuge tubes containing $20 \mathrm{~mL}$ of double deionized water. Tubes were capped and inverted 10 times to remove surface salts. The electrical conductivity of the rinsate was measured with an electrical conductivity (EC) meter (Orion Research, Boston). The linear length of twigs was measured and salt deposition was expressed per unit of twig length. When plants reached full bloom (20 May), the numbers of live and dead flower buds were counted on five randomly sampled twigs per bush. Statistical design was completely randomized with five single-plant replicates per treatment. Data were analyzed using the PROC GLM command (SAS Institute, Cary, N.C.), and linear and quadratic regression analyses were performed using MINITAB (release 13.2; State College, Pa.)

Soll SALT InUNDATION. In Dec. 2001, 25 'Jersey'blueberry plants $\approx 3$ years old in 3.8 - $\mathrm{L}$ containers were heeled into the ground in a lathouse so that the tops of the pots were $5 \mathrm{~cm}$ above the soil. The potting media was a mixture of peatmoss and sand. Plants were arranged in a completely randomized design, and five replicate plants were treated with $1 \mathrm{~L}$ of $\mathrm{NaCl}$ solutions of $0,0.017,0.051$, 0.154 , or 0.462 м on 1 Mar. 2002. Solutions were poured into the pots so that they percolated throughout the media. As buds began swelling 4 weeks later, each pot was flushed with $\approx 4 \mathrm{~L}$ of water to simulate snow-melt and spring rains that are typical in Michigan. Plants remained in the lathouse until 1 month after full bloom (20 June), when new shoot growth, leaves, flowers, and fruit were removed from each plant. Tissues were dried at $70{ }^{\circ} \mathrm{C}$ for $10 \mathrm{~d}$ and weighed. Dried soil samples were analyzed for $\mathrm{Na}$ (Thomas, 1982) and $\mathrm{Cl}$ (Hipp and Langdale, 1971) by the Michigan State Univ. (MSU) Soil and Plant Nutrient Laboratory. Data were subjected to ANOVA using the PROC GLM command (SAS), and linear and quadratic regression analyses were performed using MINITAB (release 13.2).

COLD HARDiness STUDY 1. To study the effect of salt spray on the hardiness of blueberry flower buds, five branches on 12-year-old 'Jersey' bushes in East Lansing, Mich., were sprayed to runoff with solutions of 0 (deionized water), 0.27 or $1.1 \mathrm{M} \mathrm{NaCl}$ on 21 and 22 Dec. 2002. On 23 Dec., 15 twigs at least $10 \mathrm{~cm}$ long and possessing three or more flower buds were removed from each branch. Twigs from the five branches sprayed with the same salt treatment were combined in a plastic bag containing a moist paper towel, and transported in an ice-filled cooler to the laboratory.

Within $24 \mathrm{~h}$, the twigs were prepared for controlled temperature freezing as described previously (Howell and Weiser, 1970; Stergios and Howell, 1973). Three twigs from each salt treatment were bundled together in moist cotton cheese cloth wrapped in aluminum foil. Bundles were placed in an Ultralow Freezer (ScienTemp, Adrian, Mich.) programmed to cool at a rate of $3{ }^{\circ} \mathrm{C}$ per hour. Wire thermocouples were placed between the bundles. Thermocouple wires could not be securely inserted into the tissues because the stems were woody and thin. Three bundles were placed in a cold room at $3{ }^{\circ} \mathrm{C}$, to serve as a control. Three bundles (replicates) were removed when the air temperature between the bundles reached $-17,-20,-23,-26,-29$, and $-32^{\circ} \mathrm{C}$. The rate of cooling $\left(3^{\circ} \mathrm{C} / \mathrm{h}\right)$, and decrement between sampling $(3$ ${ }^{\circ} \mathrm{C}$ ) were selected to accommodate laboratory scheduling and the quantity of plant material available. Although cooling rates of 2 ${ }^{\circ} \mathrm{C} / \mathrm{h}$ are more typical for this type of work because this cooling rate is more analogous to typical rates under natural conditions, the primary purpose of our studies was to distinguish relative effects of treatments.

After freezing, bundles were held at $3{ }^{\circ} \mathrm{C}$ for $1 \mathrm{~d}$, and $20^{\circ} \mathrm{C}$ and $100 \%$ relative humidity for $5 \mathrm{~d}$, to help distinguish between injured and healthy tissues. Buds were cross-sectioned and observed for oxidative browning using a dissecting microscope to assess flower bud viability. Brown primordia were rated as dead. The temperature resulting in $\approx 50 \%$ flower primordia mortality $\left(\mathrm{LT}_{50}\right)$ was calculated using the modified Spearmann-Karber method (Bittenbender and Howell, 1974). Linear regression analyses were performed on $\mathrm{LT}_{50}$ values using MINITAB (release 13.2).

Cold hardiness study 2. To determine the effects of road salt exposure on hardiness of blueberry flower buds, 10 -cm twigs bearing at least three contiguous flower buds were excised on $13 \mathrm{Feb}$. 2003 from 'Bluecrop' plants $\approx 50$ years old on a farm in Ottawa County, Mich. The farm was east of a major divided highway and had experienced high levels of flower bud mortality. Although the highway was treated with $\mathrm{NaCl}$ when needed through the winter, information on salt application dates and rates prior to this experiment could not be obtained. Twigs were sampled from five plants at two distances from the highway ( $\approx 65 \mathrm{~m}$ and $200 \mathrm{~m}$ ). Sampled twigs were placed in plastic bags, and transported back to East Lansing, Mich., in an ice-filled cooler for freeze-testing as described previously. Bundles containing three twigs from each field position were removed at $3{ }^{\circ} \mathrm{C} / \mathrm{h}$ temperature intervals from $-18^{\circ} \mathrm{C}$ to $-33^{\circ} \mathrm{C}$, and the $\mathrm{LT}_{50}$ was determined by sectioning the flower buds and examining for oxidative browning. The statistical model used was a split-split-plot design. Data were analyzed for ANOVA using the PROC GLM command (SAS), and linear and quadratic regression analyses were performed using MINITAB (release 13.2).

Cold HaRdiness study 3. To study the effects of lower spray concentrations of $\mathrm{NaCl}$ on cold hardiness, branches of 20-yearold 'Bluecrop' plants at a commercial blueberry field in Haslett, Mich. were treated with $0,0.068,0.137$, or $0.274 \mathrm{~m}$ on 27 and 28 Feb. 2003. Twigs were excised on 1 Mar. 2003, placed in plastic bags in an ice-filled cooler, and returned to the laboratory for controlled freezing. Twigs were prepared, frozen, and evaluated as described previously, except that the three bundle replicates were removed at slightly different temperatures, $-15,-18,-21$, $-24,-27,-30$, and $-33^{\circ} \mathrm{C}$. 
Cold haRdiness Study 4. The goal of this study was to determine how rapidly $\mathrm{NaCl}$ exposure affects flower bud cold hardiness. Branches on $\approx 12$-year-old 'Jersey' blueberry plants in East Lansing, Mich., were sprayed to run-off with $\mathrm{NaCl}$ solutions of 0 or $1.1 \mathrm{M}$ on 13 Jan. 2004. Treated branches bore at least fifteen $10 \mathrm{~cm}$-long twigs with three contiguous flower buds. Twigs were excised $1 \mathrm{~h}$ after treatment, transported back to MSU in plastic bags, and prepared within $7 \mathrm{~h}$ for cold hardiness studies. Since there were only two treatments and adequate plant material in this test, tissues were cooled at $2{ }^{\circ} \mathrm{C} / \mathrm{h}$, and three bundle replicates were removed when temperatures reached $-17,-21,-25$, and -29 ${ }^{\circ} \mathrm{C}$. Postfreezing handling and evaluation of flower primordia were the same as described previously. Statistical methods were the same as in Study 3.

Cold hardiness study 5. To compare the effects of $\mathrm{Cl}$ salts on the cold hardiness of blueberry flower buds, branches of $\approx 12$ year-old 'Jersey' blueberry plants were sprayed on 12 and 13 Jan. 2004 with deionized water, or solutions of potassium chloride $(\mathrm{KCl})$, magnesium chloride $\left(\mathrm{MgCl}_{2}\right), \mathrm{NaCl}$, and calcium chloride $\left(\mathrm{CaCl}_{2}\right)$. All solutions were adjusted to supply the same $\mathrm{Cl}$ concentration $(0.61 \mathrm{M})$ as that in $1.1 \mathrm{M} \mathrm{NaCl}$, and were applied by a hand sprayer to drip. Twigs were sampled on 14 Jan. 2004. Four bundle replicates were removed every hour at $3{ }^{\circ} \mathrm{C}$ decrements from $-16^{\circ} \mathrm{C}$ to $-31^{\circ} \mathrm{C}$. Postfreezing handling and evaluation of flower primordia were handled as in Expt. 1.

Cold HARDiness STUDY 6 . This study tested the effects of $\mathrm{Na}$ salts on the cold hardiness of blueberry flower buds. On 15 and 16 Jan. 2004, branches of 12-year-old 'Jersey' blueberry plants were sprayed with deionized water, or solutions of sodium sulfate $\left(\mathrm{Na}_{2} \mathrm{SO}_{4}\right), \mathrm{NaCl}$, or sodium acetate (Na-acetate). Solutions were standardized to the same $\mathrm{Na}$ concentration $(0.39 \mathrm{M})$ as that in $\mathrm{NaCl}$ at $1.1 \mathrm{M}$, and applied by a hand sprayer to drip. Twigs were sampled on 17 Jan. 2004. Three bundle replicates were removed every hour, at $3{ }^{\circ} \mathrm{C}$ decrements between $-16{ }^{\circ} \mathrm{C}$ to -31 ${ }^{\circ} \mathrm{C}$. Postfreezing handling and evaluation of flower primordia were handled as in previous studies.

\section{Results}

SAlt SPRAY SIMULATION. Multiple $\mathrm{NaCl}$ sprays in January and February resulted in a linear increase in flower bud mortality in May (Fig. 1). The highest $\mathrm{NaCl}$ concentration $(0.548 \mathrm{M})$ resulted in $48 \%$ mortality. Salt residues on twigs measured before each spray ranged from 2.2 to $4.2 \mu \mathrm{g} \mathrm{cm}^{-1}$ twig length, and were not affected by treatments until the last sampling date, when the highest two spray concentrations $(0.154$ and $0.462 \mathrm{M})$ resulted in significantly higher $(P<0.05)$ salt residues $\left(3.2\right.$ and $3.4 \mu \mathrm{g} \cdot \mathrm{cm}^{-1}$ twig length) than twigs sprayed with water $\left(2.2 \mu \mathrm{g} \cdot \mathrm{cm}^{-1}\right)$. Average salt residues on twigs across all spray treatments were 3.6, 2.6, $3.3,3.1$, and $2.6 \mu \mathrm{g} \cdot \mathrm{cm}^{-1}$ on each successive sampling date. The farm weather station recorded measurable precipitation on 20 of $56 \mathrm{~d}$ between the first and last salt sprays, totally $4.2 \mathrm{~cm}$.

SoIL SALT INUNDATION. Increasing $\mathrm{NaCl}$ levels applied to the soil in Mar. resulted in a linear increase in flower bud mortality by May (Fig. 2), and a decrease in dry matter production measured in June (Table 1). The highest $\mathrm{NaCl}$ rate resulted in nearly complete flower bud mortality, considerable amount of branch dieback, and vegetative buds were either killed or developed slowly. The two lowest salt application rates $\left(1\right.$ and $\left.3 \mathrm{~g} \cdot \mathrm{L}^{-1}\right)$ did not result in statistically significant effects on flower bud injury or vegetative grown, compared to the control. Even though the soil volume

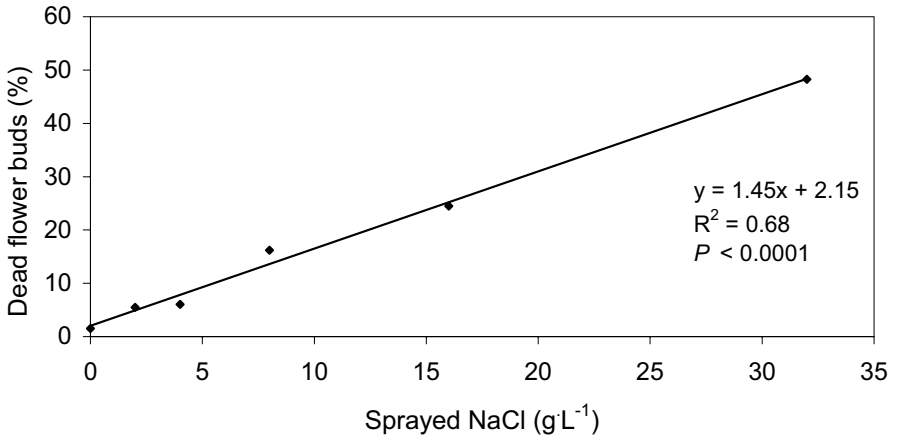

Fig. 1. Effect of $\mathrm{NaCl}$ sprays applied to 'Bluecrop' blueberry bushes on 19 Jan., 4 Feb., 18 Feb., 1 Mar., and 19 Mar., on the percentage of dead flower buds in May 2002.

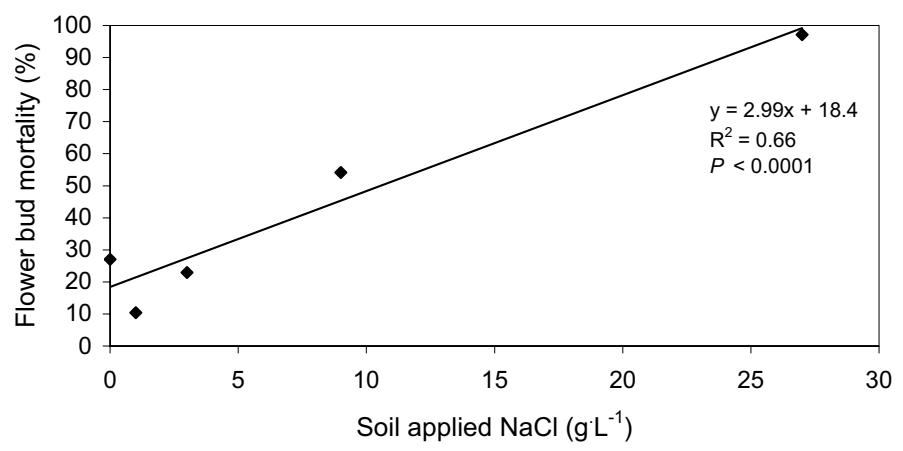

Fig. 2. Relationship between rate of $\mathrm{NaCl}$ applied to soil of potted 'Jersey' blueberry bushes in March, and flower bud mortality measured in May, 2002.

was leached with water in April, soil $\mathrm{Na}$ and $\mathrm{Cl}$ levels in May increased linearly with application rate (Table 1).

Cold hardiness study $\mathbf{1}$. $\mathrm{NaCl}$ sprays applied to 'Jersey' branches for two consecutive days in Jan. resulted in a linear reduction in flower bud hardiness (Table 2). Sprays of 0.274 and $1.1 \mathrm{M} \mathrm{NaCl}$ reduced the $\mathrm{LT}_{50}$ of buds by $8.0^{\circ} \mathrm{C}$ and $11.5^{\circ} \mathrm{C}$, respectively, compared to controls.

Cold haRdiness STUDY 2. Flower buds sampled in Feb. from bushes $65 \mathrm{~m}$ from a major divided highway in western Michigan were significantly $(P<0.0001)$ less hardy $\left(\mathrm{LT}_{50}-13.5^{\circ} \mathrm{C}\right)$ than buds from bushes $200 \mathrm{~m}$ from the highway $\left(\mathrm{LT}_{50}-31.0^{\circ} \mathrm{C}\right)$.

COLd haRdiness study 3. 'Bluecrop' branches sprayed for two consecutive days in February with $\mathrm{NaCl}$ ranging from 0 to 0.274 $\mathrm{M}$ also exhibited a linear decrease in flower bud cold hardiness measured $5 \mathrm{~d}$ later (Table 3). The highest $\mathrm{NaCl}$ concentration reduced the $\mathrm{LT}_{50}$ by $6.0^{\circ} \mathrm{C}$, compared to the control.

COLD haRdiness STUdy 4. 'Jersey' branches sprayed with $\mathrm{NaCl}$ at $1.1 \mathrm{M}$, and tested for hardiness within $7 \mathrm{~h}$ also had a significantly $(P=0.012)$ lower flower bud hardiness $\left(\mathrm{LT}_{50}-24.0\right.$ $\left.{ }^{\circ} \mathrm{C}\right)$ than control $\left(\mathrm{LT}_{50}-28.5^{\circ} \mathrm{C}\right)$.

Cold hardiness Study 5. Sprays of Cl-salt solutions $(\mathrm{NaCl}$, $\mathrm{CaCl}_{2}, \mathrm{MgCl}_{2}, \mathrm{KCl}$ ) supplying $0.61 \mathrm{M}$ Clall reduced the hardiness of 'Jersey' flower buds (Table 4). Potassium chloride resulted in the smallest reduction in cold hardiness $\left(5.0^{\circ} \mathrm{C}\right)$.

Cold hardiness Study 6. Sprays of $\mathrm{NaCl}$ and Na-acetate (supplying $0.39 \mathrm{M} \mathrm{Na}^{+}$) applied to dormant 'Jersey' branches for two consecutive days reduced the hardiness of flower buds by $5.0^{\circ} \mathrm{C}$ and $4.5^{\circ} \mathrm{C}$, respectively, compared to water-treated controls, whereas $\mathrm{Na}_{2} \mathrm{SO}_{4}$ sprays did not significantly affect hardiness (Table 5). 
Table 1. Soil $\mathrm{Na}$ and $\mathrm{Cl}$ concentrations and new dry matter production (leaves, shoots, fruit) by 20 June 2002 of potted 'Jersey' blueberry plants treated with $\mathrm{NaCl}$ solutions applied to the rootzone on 1 Mar. 2002.

\begin{tabular}{lccc}
\hline \multirow{2}{*}{$\begin{array}{l}\mathrm{NaCl} \text { applied } \\
(\mathrm{mm})\end{array}$} & $\begin{array}{c}\text { Leaf, shoot, and } \\
\text { fruit dry wt }(\mathrm{g})\end{array}$ & \multicolumn{2}{c}{ Soil salt $\left(\mathrm{mg} \cdot \mathrm{kg}^{-1}\right)$} \\
\cline { 3 - 4 } 17 & 11.0 & $\mathrm{Na}$ & $\mathrm{Cl}$ \\
\hline 0 & 11.9 & 404 & 270 \\
154 & 11.4 & 777 & 481 \\
462 & 8.7 & 1810 & 801 \\
Significance & 1.3 & 2602 & 1970 \\
$\quad$ Linear & & & 2990 \\
Quadratic & $* * *$ & $* * *$ & $* * *$ \\
\hline
\end{tabular}

*** Significant main effects at $P<0.0001$, for $\mathrm{NaCl}$ treatments partitioned into linear or quadratic orthogonal contrasts.

Table 2. Effect of $\mathrm{NaCl}$ sprays applied to branches of 'Jersey' highbush blueberry on 21 and 22 Dec. 2002, on cold hardiness of flower buds measured on 2 Jan. 2003.

\begin{tabular}{lc}
\hline $\mathrm{NaCl}$ applied $(\mathrm{M})$ & $\mathrm{LT}_{50}\left({ }^{\circ} \mathrm{C}\right)^{\mathrm{z}}$ \\
\hline 0 & -28.5 \\
0.27 & -20.5 \\
1.10 & -17.0 \\
Significance & \\
$\quad$ Linear & $* * *$ \\
\hline
\end{tabular}

zTemperature killing $50 \%$ of flower primordia.

*** Significant linear response, $P \leq 0.001$.

Table 3. Effect of $\mathrm{NaCl}$ sprays applied to branches of 'Bluecrop' blueberry on 27 and 28 Feb. on the cold hardiness of flower buds measured on 9 Mar.

\begin{tabular}{lc}
\hline $\mathrm{NaCl}$ applied $(\mathrm{M})$ & $\mathrm{LT}_{50}\left({ }^{\circ} \mathrm{C}\right)^{\mathrm{z}}$ \\
\hline 0 & -22.5 \\
0.068 & -18.0 \\
0.137 & -19.5 \\
0.274 & -16.5 \\
Significance & \\
$\quad$ Linear & $* * *$ \\
$\quad$ Quadratic & $* * *$
\end{tabular}

zTemperature killing $50 \%$ of flower primordia.

${ }^{* * *}$ Significant at $P \leq 0.001$

Table 4. Effect of salt solutions supplying $0.61 \mathrm{M} \mathrm{Cl}$ applied to 'Jersey' blueberry branches of on 13 and $14 \mathrm{Jan}$. on the cold hardiness of flower buds measured on 21 Jan.

\begin{tabular}{lc}
\hline Treatment & $\mathrm{LT}_{50}\left({ }^{\circ} \mathrm{C}\right)^{\mathrm{z}}$ \\
\hline $\mathrm{Control}$ & $-26.0 \mathrm{a}^{\mathrm{y}}$ \\
$\mathrm{KCl}$ & $-21.5 \mathrm{~b}$ \\
$\mathrm{MgCl}_{2}$ & $-18.0 \mathrm{c}$ \\
$\mathrm{CaCl}_{2}$ & $-17.5 \mathrm{c}$ \\
$\mathrm{NaCl}$ & $-16.0 \mathrm{c}$ \\
$P$ & $<0.0001$
\end{tabular}

zTemperature killing $50 \%$ of flower primordia. yMeans within columns followed by a different letter are significantly different by Tukey's honestly significantly different test $(P=0.05)$.
Table 5. Effect of salt solutions supplying $0.39 \mathrm{~m} \mathrm{Na}$ applied to 'Jersey' blueberry branches on 15 and 16 Jan. 2004, on the cold hardiness of flower buds measured on 23 Jan.

\begin{tabular}{lc}
\hline Treatment & $\mathrm{LT}_{50}\left({ }^{\circ} \mathrm{C}\right)^{z}$ \\
\hline Control & $-20.0 \mathrm{a}^{\mathrm{y}}$ \\
$\mathrm{Na}_{2} \mathrm{SO}_{4}$ & $-19.0 \mathrm{a}$ \\
$\mathrm{Na}-\mathrm{acetate}$ & $-15.5 \mathrm{~b}$ \\
$\mathrm{NaCl}$ & $-15.0 \mathrm{~b}$ \\
$P$ & $<0.0001$ \\
\hline zTemperature killing 50\% of flower primordia. \\
yMeans within columns followed by a different let- \\
ter are significantly different by Tukey's honestly \\
significantly different test $(P=0.05)$.
\end{tabular}

\section{Discussion}

These studies indicate that the shoot dieback and flower bud mortality observed in blueberry fields adjacent to salted roads in west Michigan (Berkheimer, 2004) can be duplicated by treating dormant bushes with multiple sprays of $\mathrm{NaCl}$ or applying moderate rates of $\mathrm{NaCl}$ to the soil. These results, combined with field observations that injury and salt deposition levels on twigs increase with proximity to roads (Berkheimer, 2004), indicate that deicing salts are responsible for the flower bud loss on blueberry farms in western Michigan. Deicing salt has been shown to cause similar injury to lowbush blueberry (Eaton et al., 1999), peach (Northover, 1987) and various ornamental tree species (Barrick and Davidson, 1980; Sucoff, 1975).

Most of the injury in blueberry fields appears to result from salt spray that is generated by traffic and deposited directly onto bushes by wind, rather than salt accumulation in the soil. Plants close to highways typically exhibited partial to complete flower bud mortality by spring, but grew and appeared normal by midsummer, although fruit were absent (Berkheimer, 2004). These symptoms were identical to those caused by multiple salt sprays in this study. In contrast, bushes treated with the two higher rates of soil-applied $\mathrm{NaCl}$ suffered severely reduced vegetative growth (Table 1) in addition to flower bud injury (Fig. 2). Thompson and Rutter (1986) also observed that soil applications of salt often killed woody shrubs, whereas sprays usually resulted in dieback followed by regrowth. The fact that blueberry bushes are injured up to $100 \mathrm{~m}$ from roads (Berkheimer, 2004) also suggests spray injury rather than excessive soil salt, since excessive soil salt tends to be a problem closer to roadways (Bryson and Barker, 2002; Thompson et al., 1986; Hofstra et al., 1979).

Bushes closest to heavily traveled highways may be affected by both salt spray and elevated soil salt levels, since injury included flower bud loss and dieback of larger branches and shoots (Berkheimer, 2004). Residual salt in soils or plant tissues may increased injury in subsequent seasons. Carryover of salt could be confirmed by monitoring salt levels in soils and plant tissues over time and with distance from salted roads. Pedersen et al. (2000) reported that $\mathrm{Na}$ and $\mathrm{Cl}$ accumulated in soils adjacent to salted roads from one year to the next, and others have speculated that deicing salts may accumulate in roadside soils over years (Bryson and Barker, 2002; Lumis et al., 1976; Sucoff, 1975; Westing, 1969).

Salt residues on twigs treated with repeated $\mathrm{NaCl}$ sprays were similar to those measured on twigs adjacent to salted roads (Berkheimer, 2004), which provides confidence that deicing salt spray is responsible for injury to plants in blueberry fields. Although 
the highest spray concentrations resulted in higher salt residue on twigs after the last sprays, residues did not generally increase with each successive spray, as might be expected. Similarly, twigs on roadside bushes did not consistently accumulate salt during the winter months (Berkheimer, 2004). Since measurable rain or snow fell on 20 days between the first and last salt sprays, rain or melting snow dripping from the lathouse roof onto plants may have washed some salt from the twigs, and precipitation events may also remove residues from bushes in the field. Treatments in our soil inundation study were applied in late winter when salt is expected to accumulate in roadside soils (Foster and Maun, 1978; Pedersen et al., 2000), and pots were flushed with water in early spring to simulate snow-melt and spring rains that are typical in Michigan. Even after pots were flushed and irrigated several times, salt levels remained high in treated soils (2602 $\mathrm{mg} \cdot \mathrm{kg}^{-1} \mathrm{Na}, 2990 \mathrm{mg} \cdot \mathrm{kg}^{-1} \mathrm{Cl}$ ). Levels in treated soils are similar to those measured at various distances from a highway in Ontario (Foster and Maun, 1978). Pedersen et al. (2000) also reported very high levels of salt within $2 \mathrm{~m}$ of a salted road, but did not analyze specifically for $\mathrm{Na}$ and $\mathrm{Cl}$. The highest soil $\mathrm{Na}$ levels next to salted roads in Massachusetts (300 $\mathrm{mg} \cdot \mathrm{kg}^{-1}$ ), occurred within $3 \mathrm{~m}$ of the pavement (Bryson and Barker, 2002).

Control pots also contained moderate levels of $\mathrm{Na}\left(95 \mathrm{mg} \mathrm{kg}^{-1}\right)$ and $\mathrm{Cl}\left(270 \mathrm{mg} \cdot \mathrm{kg}^{-1}\right)$ after flushing. Although soil $\mathrm{Na}$ or $\mathrm{Cl}$ levels higher than $200 \mathrm{mg} \cdot \mathrm{kg}^{-1}$ may cause injury to glycophytic and halophytic plant species (Salinity Lab. Staff, 1954), our plants were grown in an artificial peat moss based media that is commonly used by nurseries producing blueberry plants. Since salt hazard is affected by soil texture, moisture, and the content of other cations, it is not known whether $\mathrm{Na}$ and $\mathrm{Cl}$ levels in control plants affected plant growth. Comparing the affects of specific salt levels in this artificial media with those in roadside soils may also be misleading.

Salt sprays decreased the cold hardiness of blueberry flower buds by up to $11^{\circ} \mathrm{C}$ (Tables 2-5), and the hardiness of buds exposed to road salt spray was reduced by over $17^{\circ} \mathrm{C}$ (Study 2$)$. The magnitude of the reduction is significant since winter injury often reduces blueberry yields in Michigan, and even a slight reduction in hardiness can result in considerable losses during cold years. For comparison, some of the most hardy and least hardy blueberry varieties grown in Michigan differed in mid-winter hardiness by less than $5^{\circ} \mathrm{C}$ (Bittenbender and Howell, 1976). A $17^{\circ} \mathrm{C}$ reduction in hardiness could explain the amount of flower bud injury observed in roadside blueberry fields (Berkheimer, 2004), which was more extensive following colder winters than a mild winter. The hardiness of other woody species was reduced by exposure to either ambient road salt spray (Sucoff et al., 1976; Sucoff and Hong, 1976) or applied $\mathrm{NaCl}$ sprays (Sucoff and Hong, 1976).

How salt exposure reduces hardiness is not known. Sucoff and Hong (1976) speculated that $\mathrm{NaCl}$ may reduce hardiness by decreasing tissue moisture content or inactivating phosphorylation, and questioned whether injury to roadside plants was a toxic reaction to $\mathrm{Na}$ or $\mathrm{Cl}$, or cold injury resulting from reduced hardiness. In our cold hardiness studies, salt sprays did not injure buds unless tissues were subsequently frozen (data not shown). In addition, all $\mathrm{Cl}$ and $\mathrm{Na}$ salts tested, except $\mathrm{Na}_{2} \mathrm{SO}_{4}$, reduced hardiness to some degree (Tables 4 and 5), so the effect was not specific to either $\mathrm{Cl}$ or $\mathrm{Na}$.

Interestingly, buds collected $1 \mathrm{~h}$ after salt treatment and tested for hardiness within $7 \mathrm{~h}$ also were less hardy (Study 4). The fact that hardiness was affected so quickly and not specific to one ion suggests that salts may compromise hardiness through a physical mechanism. Tissues in these studies were dormant and maintained below $5^{\circ} \mathrm{C}$ between treatment and controlled freezing. It is unclear how salt applied to the exterior of dormant buds could induce rapid physiological effects at these temperatures.

Dormant flower buds of many species, including blueberry, tolerate cold by supercooling (Quamme, 1991). Primordia are able to cool below their freezing point by remaining isolated from ice crystals and other ice nucleating sites. In peach and Rhododendron L. species, water migrates out of the tissues at the axis of buds and into the bud scales where ice forms without injury. The dehydrated tissues in bud axes form a barrier that prevents ice crystals in stems from seeding ice in flower primordia (Ishikawa and Sakai, 1981; Quamme, 1978). Xylem does not connect blueberry stems and flower buds until growth resumes in the spring (Flinn and Ashworth, 1994), which may also prevent ice in the xylem of stem tissues from seeding ice in dormant flower primordia. Ishikawa and Sakai (1981) speculated that the scales and cuticle of Rhododendron flower buds also isolate flower primordia from contact with external ice crystals.

How salt residues on the surface of blueberry flower buds might compromise the ability of primordia to supercool is not clear. Perhaps salt inhibits ice formation within bud scales, which prevents the scales from isolating primordia from external ice crystals. If ice formation in bud scales is necessary to dehydrate flower primordia, perhaps salt also inhibits desiccation of flower primordia or tissues in the axis of buds. Interestingly, when flower buds were dissected after our freezing tests, the edges of salttreated bud scales often appeared more curled and tattered than those of control buds. Although dehydration of blueberry flower buds was associated with acclimation to cold (Bittenbender and Howell, 1975), excessive dehydration is lethal to cells (Kuroda et al., 2003).

If salt on bud surfaces prevents ice from forming in bud scales and reduces water movement out of flower primordia, salts with a higher affinity for water should have a greater effect. One property of salts that may affect their ability to desiccate flower buds is the hydration of the salt ions (Foth, 1978). Cold hardiness was affected most severely by $\mathrm{NaCl}$ compared to $\mathrm{Na}_{2} \mathrm{SO}_{4}$, $\mathrm{NaAC}, \mathrm{MgCl}_{2}, \mathrm{CaCl}_{2}$, and $\mathrm{KCl}$. Based on $\mathrm{LT}_{50}$ levels, $\mathrm{KCl}$ might be less injurious to roadside plants than $\mathrm{NaCl}$. The lowest effective temperature of $\mathrm{KCl}\left(-11.0^{\circ} \mathrm{C}\right)$ is lower than that of $\mathrm{NaCl}$ $\left(-8.0^{\circ} \mathrm{C}\right)$, so this should not exclude $\mathrm{KCl}$ from use as a possible deicing alternative to $\mathrm{NaCl}$.

Results of these studies, along with field observations (Berkheimer, 2004), indicated that deicing salt can injure blueberry plants adjacent to salted roads. Wind-blown spray appears to cause most damage, but plants closest to roads may also be affected by high soil salt levels. Salt spray appears to injure blueberry flower buds by reducing their tolerance to cold. Results suggest that salt reduces hardiness through a physical effect rather than ion toxicity, but this mechanism is not clear.

\section{Literature Cited}

Barrick, W.E. and H. Davidson. 1980. Deicing salt spray injury in norway maple as influenced by temperature and humidity conditions. HortScience 15:203-206.

Berkheimer, S.F. 2004. Deicing salt injury to highbush blueberry (Vaccinium corymbosum L.) in west Michigan. MS Thesis. Michigan State Univ., East Lansing.

Bittenbender, H.C. and G.S. Howell. 1974. Adaptation of the Spearman-Karber method for estimating the T50 of cold stressed flower buds. J. Amer. Soc. Hort. Sci. 99:187-190.

Bittenbender, H.C. and G.S. Howell. 1975. Interactions of temperature 
and moisture content of spring de-acclimation of flower buds of highbush blueberry. Can. J. Plant Sci. 55:447-452.

Bittenbender, H.C. and G.S. Howell. 1976. Cold hardiness of flower buds from selected highbush blueberry cultivars. J. Amer. Soc. Hort. Sci. 101:135-139.

Bowers, M.C. and J.H. Hesterberg. 1976. Environmental implications of highway deicing agents on white pine in Marquette County, Michigan. The Michigan Botanist 15:75-89.

Bryson, G.M. and A.V. Barker. 2002. Sodium accumulation in soils and plants along Massachusetts's roadsides. Commun. Soil Sci. Plant Anal. 33:67-78.

Eaton, L.J., J. Hoyle, and A. King. 1999. Effect of deicing salt on lowbush blueberry flowering and yield. Can. J. Plant Sci. 79:125-128.

Eaton, L. J., K. R. Sanderson, and J. Hoyle. 2004. Effect of salt deposition from salt water spray on lowbush blueberry shoots. Small Fruits Rev. 3:95-103.

Flinn, C.L. and E.N. Ashworth. 1994. Seasonal changes in ice distribution and xylem development in blueberry flower buds. J. Amer. Soc. Hort. Sci. 119:1176-1184.

Foster, A.C. and M.A. Maun. 1978. Concentration of highway deicing agents along roadsides near London. Can. J. Bot. 56:1081-1085.

Foth, H.D. 1978. Fundamentals of soil science. $6^{\text {th }}$ ed. Wiley, New York.

Hipp, B.W. and G.W. Langdale. 1971. The use of solid state chloride electrode for chloride determination in soil extracts. Commun. Soil Sci. Plant Anal. 2:237.

Hofstra, G., R. Hall, and G. Lumis. 1979. Studies on salt-induced damage to roadside plants in Ontario. J. Arboriculture 5:25-31.

Howell, G.S. and C.J. Weiser. 1970. Fluctuations in the cold resistance of apple twigs during spring dehardening. J. Amer. Soc. Hort. Sci. 95:190-192.

Ishikawa, M. and A. Sakai. 1981. Freezing avoidance mechanisms by supercooling in some Rhododendron flower buds with reference to water relations. Plant Cell Physiol. 22:953-967.

Kuroda, K., J. Kasuga, K. Arakawa, and S. Fujikawa. 2003. Xylem ray parenchyma cells in boreal hardwood species respond to subfreezing temperatures by deep supercooling that is accompanied by incomplete desiccation. Plant Physiol. 131:736-744.

Lumis, G.P., G. Hofstra, and R. Hall. 1976. Roadside woody plant susceptibility to sodium and chloride accumulation during winter and spring. Can. J. Plant Sci. 56:853-859.

Michigan Department of Transportation. 1993. The use of selected deicing materials on Michigan roads: Environmental and economic impacts. Public Sector Consultants (with MDOT). Lansing, Mich.
Marschner, H. 1995. Mineral nutrition of higher plants. Academic, San Diego, Calif.

Northover, J. 1987. NaCl injury to dormant roadside peach trees and its effect on the incidence of infections by Leucostoma spp. Phytopathology 77:835-840.

Paludan-Muller, G., H. Saxe, L.B. Pedersen, and T.B. Randrup. 2002. Differences in salt sensitivity of four deciduous tree species to soil or airborne salt. Physiol. Plant. 114:223-230.

Pedersen, L.B., T.B. Randrup, and M. Ingerslev. 2000. Effects of road distance and protective measures on deicing $\mathrm{NaCl}$ deposition and soil solution chemistry in planted median strips. J. Arboriculture 26:238-244.

Quamme, H.A. 1978. Mechanism of supercooling in overwintering peach flower buds. J. Amer. Soc. Hort Sci. 103:57-61.

Quamme, H.A. 1991. Application of thermal analysis to breeding fruit crops for increased cold hardiness. HortScience 26:513-517.

Salinity Laboratory Staff. 1954. Diagnosis and improvement of saline and alkaline soils. Agriculture Handbook \#60, USDA. U.S. Government Printing Office, Washington, D.C.

Stergios, B.G. and G.S. Howell. 1973. Evaluation of viability tests on cold stressed plants. J. Amer. Soc. Hort Sci. 98:325-330.

Sucoff, E. 1975. Effect of deicing salts on woody vegetation along minnesota roads; Final report, 1975. Investigation \#636, Minn. Agr. Expt. Sta. Tech. Bul. 303.

Sucoff, E. and S.G. Hong. 1976. Effects of $\mathrm{NaCl}$ on cold-hardiness of Malus spp. and Syringa vulgaris. Can. J. Bot. 54:2816-2819.

Sucoff, E., S.G. Hong, and A. Wood. 1976. $\mathrm{NaCl}$ and twig dieback along highways and cold hardiness of highway versus garden twigs. Can. J. Bot 54:2268-2274.

Thomas, G.W. 1982. Exchangeable cations, p. 159-165. In: A.L. Page et al. (ed.). Methods of soil analysis, Part II. 2nd ed. Agronomy Monograph 9. ASA and SSSA, Madison, Wis.

Thompson, J.R. and A.J. Rutter. 1986. The salinity of motorway soils. IV. Effects of sodium chloride on some native British shrub species, and the possibility of establishing shrubs on the central reserves of motorways. J. Appl. Ecol. 23:299-315.

Thompson, J.R., A.J. Rutter, and P.S. Ridout. 1986. The salinity of motorway soils II. Distance from the carriageway and other sources of local variation in salinity. J. Appl. Ecol. 23:269-280.

Westing, A.H. 1969. Plants and salt in the roadside environment. Phytopathology 59:1174-1181.

Zobel, A. and J.E. Nighswander. 1990. Accumulation of phenolic compounds in the necrotic areas of austrian and red pine needles due to salt spray. Ann. Bot. 66:629-640. 